1999

INDEX

Articles

by Author
Arpaly, Nomy, and Timothy Schroeder,

Alienation and Externality . . . . . . . . . . . 371

Bigelow, John, and Robert Pargetter,

Critical Notice of Tim Crane, Ed.,

Dispositions: A Debate by D.M. Armstrong,

C.B. Martin and U.T. Place . . . . . . . . . . . . . 619

Blanchette, Patricia, Relative Identity and Cardinality . . 205

Buss, Sarah, Respect for Persons . . . . . . . . . . . 517

Carlson, Allen A., and Glenn G. Parsons,

Critical Notice of Eddy M. Zemach, Real Beauty . . . . . 635

Dimock, Susan, Defending Non-Tuism . . . . . . . . . 251

Franceschi, Paul, Comment l'urne de Carter et

Leslie se déverse dans celle de Hempel . . . . . . . . . . 139

Haji, Ishtiyaque, Moral Anchors and Control . . . . . . 175

Keating, Laura, Mechanism and the Representational

Nature of Sensation in Descartes . . . . . . . . . . 411

LeBar, Mark, Kant on Welfare . . . . . . . . . . . . 225

Levine, Michael, Critical Notice of J.J.C. Smart

and J.J. Haldane, Atheism and Theism . . . . . . . 157

Mandle, Jon, The Reasonable in Justice as Fairness . . . 75

McCormick, Miriam, A Change in Manner: Hume's

Scepticism in the Treatise and The First Enquiry . . . 431

Montminy, Martin, Fodor's Very Deep Thought . . . . . 595

Murray, Robert, Liberalism, Culture,

Aboriginal Rights: In Defence of Kymlicka . . . . . . . . 109

Noggle, Robert, Kantian Respect and Particular Persons 449

Pargetter, Robert, and John Bigelow,

Critical Notice of Tim Crane, Ed.,

Dispositions: A Debate by D.M. Armstrong,

C.B. Martin and U.T. Place . . . . . . . . . . . . . 619

Parsons, Glenn G., and Allen A. Carlson,

Critical Notice of Eddy M. Zemach, Real Beauty . . . . . 635

Saidel, Eric, Critical Notice of Andy Clark, Being There 299

Saul, Jennifer, The Best of Intentions:

Ignorance, Idiosyncrasy, and Belief Reporting . . . . . . 29 
Savitt, Steven F, Critical Notice of John Earman,

Bangs, Crunches, Whimpers, and Shrieks . . . . 479

Schroeder, Timothy and Nomy Arpaly,

Alienation and Externality . . . . . . . . . . . 371

Shapiro, Lionel, Toward 'Perfect Collections of

Properties': Locke on the Constitution of Substantial Sorts

Soames, Scott, The Indeterminacy of

Translation and the Inscrutability of Reference . . . . . . . 321

Sypnowich, Christine,

Critical Notice of K. Anthony Appiah and Amy Gutmann,

Color Conscious . . . . . . . . . . . . . . . 275

Szabados, Béla, Was Wittgenstein an Anti-Semite?

The Significance of Anti-Semitism for Wittgenstein's

Philosophy ................... 1

Thompson, Janna, Inherited Obligations and

Generational Continuity . . . . . . . . . . . . . 493

Wong, Wai-hung, Interpretive Charity, Massive

Disagreement, and Imagination . . . . . . . . . . . . 49

Zimmerman, Michael J., In Defense of the

Concept of Intrinsic Value . . . . . . . . . . . . . . . . 389 
1999

Alienation and Externality,

INDEX

Timothy Schroeder and Nomy Arpaly . . . . . . . 371

Articles

by Title

The Best of Intentions: Ignorance, Idiosyncrasy, and Belief Reporting, Jennifer Saul . . . . . . . . . 29

A Change in Manner: Hume's Scepticism in the

Treatise and the first Enquiry, Miriam McCormick . . . 431

Comment l'urne de Carter et Leslie se déverse

dans celle de Hempel, Paul Franceschi . . . . . . . . . 139

Critical Notice of K. Anthony Appiah and

Amy Gutmann, Color Conscious, Christine Sypnowich 275

Critical Notice of Tim Crane, Ed.,

Dispositions: A Debate by D.M. Armstrong,

C.B. Martin and U.T. Place,

John Bigelow and Robert Pargetter . . . . . . . . . . 619

Critical Notice of Andy Clark,

Being There, Eric Saidel . . . . . . . . . . . . . . . . 299

Critical Notice of John Earman, Bangs,

Crunches, Whimpers, and Shrieks, Steven F. Savitt . . 479

Critical Notice of J.J.C. Smart and J.J. Haldane,

Atheism and Theism, Michael Levine . . . . . . . . . 157

Critical Notice of Eddy M. Zemach,

Real Beauty, Allen A. Carlson and Glenn G. Parsons . . 635

Defending Non-Tuism, Susan Dimock . . . . . . . . . 251

Fodor's Very Deep Thought, Martin Montminy . . . 595

In Defence of the Concept of Intrinsic Value,

Michael J. Zimmerman . . . . . . . . . . . . . . . . 389

The Indeterminacy of Translation and the Inscrutability of Reference, Scott Soames . . . . . . . 321

Inherited Obligations and Generational

Continuity, Janna Thompson . . . . . . . . . . . . . 493

Interpretive Charity, Massive Disagreement,

and Imagination, Wai-hung Wong . . . . . . . . . . 49

Kant on Welfare, Mark LeBar . . . . . . . . . . . . 225

Kantian Respect and Particular Persons, Robert Noggle 449

Liberalism, Culture, Aboriginal Rights:

In Defence of Kymlicka, Robert Murray . . . . . . . 109 
Mechanism and the Representational Nature of Sensation in Descartes, Laura Keating . . . . . . . . 411 Moral Anchors and Control, Ishtiyaque Haji . . . . 175 The Reasonable in Justice as Fairness, Jon Mandle . . . 75 Relative Identity and Cardinality, Patricia Blanchette . 205 Respect for Persons, Sarah Buss . . . . . . . . . 517

Toward 'Perfect Collections of Properties':

Locke on the Constitution of Substantial Sorts,

Lionel Shapiro . . . . . . . . . . . . . . . . . . 551

Was Wittgenstein an Anti-Semite?

The Significance of Anti-Semitism for

Wittgenstein's Philosophy, Béla Szabados . . . . . . . 1 
Information for Authors

\section{Avis aux auteurs}

The purpose of the Canadian Journal of Philosophy is the publication in Canada of philosophical work of high quality, in English or French, and in any field of philosophy. All submissions are given blind editorial review; those of departmental colleagues are externally refereed.

Four copies of submitted manuscripts, double-sided if preferred, should be sent to: Executive Secretary, Canadian Journal of Philosophy, University of Lethbridge, Lethbridge, Alberta, Canada T1K 3M4. It is preferred that manuscripts be typed double-spaced, including quotes and footnotes. In general, the Canadian Journal of Philosophy follows The University of Chicago Manual of Style. Footnotes should be numbered consecutively and assembled on separate pages at the end of the manuscript. Manuscripts should be prepared for blind review, which means they should contain no self-identifying references in either text or footnotes. Manuscripts will not be returned unless return postage is prepaid by cheque, money-order, reply coupons, or Canadian stamps.

Authors will receive, without charge, 25 copies of their articles. Additional offprints may be ordered when the proofs are returned to the publisher.

The articles in CIP are indexed in The Philosophers' Index, Bowling Green, Ohio, USA, the Répertoire bibliographique de la philosophie, Louvain, Belgium, The Modern Language Association Directory of Periodicals, the Humanities Index, the International Bibliography of the Social Sciences, and the Canadian Periodical Index.

All enquiries of an editorial nature should be directed to the Executive Secretary at the above address.

The Canadian Journal of Philosophy a pour objet la publication canadienne, en langues anglaise ou française, d'études philosophiques de haut niveau, quel que soit le domaine philosophique auxquelles elles appartiennent. Les communications sont évaluées dans l'anonymat de leurs auteurs; celles que soumettent les collègues départementaux sont référées à un comité de lecture extérieur.

Les manuscrits, en quatre exemplaires, doivent être adressés à La Secrétaire à la Rédaction. Canadian Journal of Philosophy, University of Lethbridge, Lethbridge, Alberta, Canada T1K 3M4. Soumettre de préférence des manuscrits (citations et notes comprises) dactylographiés à double interligne, en prenant pour guide, dans la mesure du possible, The University of Chicago Manual of Style. Les notes doivent suivre la numérotation continue et figurer sur des feuilles indépendantes en annexe au manuscrit. Les manuscrits devraient être préparé pour l'évaluation anonyme par les pairs. Il ne doit pas par conséquent contenir aucune référence, que ce soit dans le texte ou dans les notes, qui pourrait servir à identifier l'auteur. Les textes non insérés ne sont rendus qu'en cas de prépaiement des frais de poste par chèque, mandat, coupons-réponse, ou timbres canadiens.

Les auteurs recoivent gratuitement 25 tirés-à part de leur article. Ils sont priés, s'ils désirent en obtenir un plus grand nombre à titre onéreux, en informer l'imprimeur lors de renvoi des épreuves.

Les articles du CJP sont catalogués dans The Philosophers' Index, Bowling Green, Ohio, E-U, le Répertoire bibliographique de la philosophie, Louvain, Belgique, The Modern Language Association Directory of Periodicals, Humanities Index, International Bibliography of the Social Sciences et l'Index de Périodiques Canadiens. 
Subscription Information
Canadian Journal of Philosophy is published by the University of Calgary Press.

Canadian Journal of Philosophy is published quarterly, in March, June, September, and December. In addition to these regular issues, CIP publishes annually a supplementary volume of original papers on a selected theme of contemporary philosophical interest. This supplementary volume is free to all subscribers to the journal in that year. Supplementary volumes may also be purchased separately from Raincoast Books, 8680 Cambie St., Vancouver, BC V6P 6M9.

Correspondence regarding subscriptions, renewals, and single issues should be addressed to Canadian Journal of Philosophy c/o University of Calgary Press, The University of Calgary, Calgary, Alberta, Canada T2N 1N4.

A subscription for the 2000 volume of four issues plus the supplementary volume is:

$\begin{array}{lrr} & \text { Canada } & \text { Outside Canada } \\ \text { Institutions } & \text { Cdn. } \$ 50.00 & \text { US } \$ 50.00 \\ \text { Individuals } & 25.00 & 25.00 \\ \text { Students } & 15.00 & 15.00 \\ \text { Single issues } & 9.00 & 9.00\end{array}$

Subscribers to the Canadian Journal of Philosophy are eligible for a discounted subscription to the Australasian Journal of Philosophy, as are Australasian Journal subscribers to the Canadian Journal. For information contact the University of Calgary Press as below.

\section{Canadian
Journal of
Philosophy}

University of Calgary Press

The University of Calgary

CALGARY, Alberta, Canada T2N 1N4

403-220-7736 Fax 403-282-0085

Email: wgee@ucalgary.ca

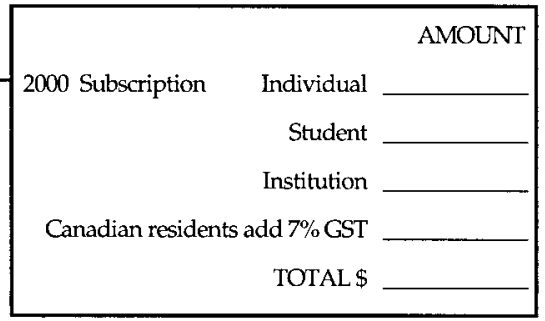

TOTAL $\$$

Please send me information on CJP Supplementary Volumes $\square$

Name

Address

City

Country Postal Code

Visa $\square \quad$ Mastercard $\square \quad$ No

Expiry Date

Cheques should be made payable to University of Calgary Press. 
Abonnements

Canadian Journal of Philosophy est publié par University of Calgary Press.

Canadian Journal of Philosophy est une publication trimestrielle paraissant en mars, juin, septembre, et décembre. Outre ses quatre fascicules réguliers, il publie, annuellement, un supplément thématique d'articles inédits consacrés à des sujets d'actualité philosophique. Le supplément est offert gratuitement à tout abonné de l'année courante. Les suppléments sont également disponibles à titre onéreux à Raincoast Books, 8680 Cambie St., Vancouver, BC V6P 6M9.

Toute correspondance concernant l'administration (abonnements, renouvellements, commandes de numéros) doit être adressée à Canadian Journal of Philosophy, c/o University of Calgary Press, The University of Calgary, Calgary, Alberta, Canada T2N $1 \mathrm{~N} 4$.

Tarifs d'abonnement au volume 2000 (4 fascicules et de suppléments):

$\begin{array}{lrr} & \text { Canada } & \text { Hors-Canada } \\ \text { Institutions } & \text { Cdn. } 50,00 \$ & \text { US 50,00\$ } \\ \text { Individus } & 25,00 \$ & 25,00 \$ \\ \text { Etudiants } & 15,00 \$ & 15,00 \$ \\ \text { Numéro simple } & 9,00 \$ & 9,00 \$\end{array}$

Lesabonnés de Canadian Journal of Philosophy peuventbénéficierd'un rabais pour l'abonnement à l'Australasian Journal of Philosophy. Les abonnés de cette dernière revue peuvent eux aussi bénéficier d'un rabais pour Canadian Journal of Philosophy. Pour de plus amples renseignements, prière de contacter les Presses de l'Université de Calgary à l'adresse indiquée ci-bas.

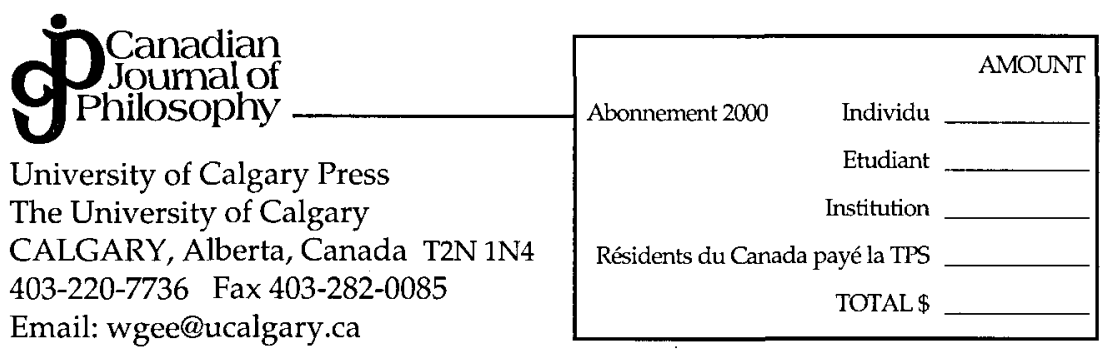

Veuillez me faire parvenir tous les renseignements concernant les suppléments du CJP

Nom

Adresse

Ville

Pays Code Postal

Visa $\square \quad$ Mastercard $\square \quad$ No.

Date d'expiration

Libeller tout chèque à l'ordre de University of Calgary Press. 


\author{
Other \\ Business \\ Information
}

Automatic
Permission
to Reproduce

Back Issues

Services
administratifs
— détails
supplémen-
taires

Reproduction

affranchie

d'agrément préalable
All business correspondence should be addressed to Canadian Journal of Philosophy, University of Calgary Press, Calgary, Alberta T2N $1 \mathrm{~N} 4$. This includes enquiries concerning advertising and promotion, exchanges, and reprinting. The copyright for all materials appearing in the regular issues and in the supplements of this journal is held by the Canadian Journal of Philosophy, and consent for any reproduction or reprinting must be obtained with the following exception.

Permission to reproduce parts of individual numbers of Canadian Journal of Philosophy by photocopy, xerox, offset, etc., for scholarly purposes (but not for republishing by printing nor for sale to the public) is automatically granted without prior permission being secured at the following rates: first 5 copies, no charge; 5 cents for each copy in excess of five of each page of CJP.

Remuneration is to be paid to the Canadian Journal of Philosophy, stating title and author of the article and number of copies. Proceeds above $\$ 10.00$ from any one article will be shared with the author. This announcement applies retroactively to volume I, number 1 .

Canadian Journal of Philosophy is indexed in Canadian Magazine Index by Micromedia Limited.

Toute correspondance administrative, à l'exception de celle qui concerne les abonnements, renouvellements et commandes de numéros et de suppléments, doit être adressée aux Canadian Journal of Philosophy, University of Calgary Press, Calgary, Alberta T2N $1 \mathrm{~N} 4$. Ecrire à l'adresse ci-dessus pour tous renseignements relatifs à la publicité et à la promotion, ainsi qu'aux échanges et aux réimpressions. Le copyright des articles afférents aux fascicules et suppléments est propriété du Canadian Journal of Philosophy. Leur reproduction ou réimpression en tout ou partie ne peut être faite sans l'agrément préalable de le Directeur de la Publication, sauf dans le cas suivant.

Est affranchie d'agrément préalable la reproduction partielle des numéros du Canadian Journal of Philosophy par procédé technique de photocopie, xerox, offset, etc., lorsqu'elle vise exclusivement à des fins ou à des recherches académiques. Est interdite toute réimpression ayant pour objet la vente au public. Conditions tarifaires de reproduction: 1-5 copies, accordé à titre gracieux; 6 copies ou en plus, 5 cents pour chaque copie de chaque page du CJP.

Effectuer tout règlement à l'ordre du Canadian Journal of Philosophy. Avoir soin d'indiquer le nom de l'auteur et le titre de l'article à reproduire d'une part, et le nombre de copies requises, de l'autre. Les apports provenant d'un article sont partagés à égalité avec son auteur pour la part numéraire dépassant $\$ 10.00$ (règlement rétroactif au volume I, No. 1).

Canadian Journal of Philosophy est répertoirié par Micromedia ltée dans le Canadian Magazine Index. 


\section{CANADIAN JOURNAL OF PHILOSOPHY SUPPLEMENTARY VOLUMES}

\begin{tabular}{|c|c|c|c|c|}
\hline & & & $\begin{array}{c}\text { Retail } \\
\text { in } \\
\text { Canada } \\
\text { Cdn. } \$ \$\end{array}$ & $\begin{array}{c}\text { Retail } \\
\text { outside } \\
\text { Canada } \\
\text { US } \$ \$\end{array}$ \\
\hline \multirow[t]{4}{*}{ Vol. I } & -1975 & Part 1: New Essays in the & & \\
\hline & & History of Philosophy & 10.00 & 10.00 \\
\hline & & Part 2: New Essays in the & & \\
\hline & & Philosophy of Mind & 10.00 & 10.00 \\
\hline \multirow{2}{*}{$\begin{array}{l}\text { Vol. III } \\
\text { Vol. IV }\end{array}$} & -1977 & New Essays in Contract Theory & 13.00 & 13.00 \\
\hline & -1978 & $\begin{array}{l}\text { New Essays in Rationalism } \\
\text { and Empiricism }\end{array}$ & 1300 & 13.00 \\
\hline \multirow[t]{2}{*}{ Vol. V } & -1979 & New Essays on Mill and & & \\
\hline & & Utilitarianism & 13.00 & 13.00 \\
\hline \multirow[t]{2}{*}{ Vol. VI } & -1980 & New Essays in Philosophy of & & \\
\hline & & Language & 13.00 & 13.00 \\
\hline Vol. VII & -1981 & Marx and Morality & 15.00 & 15.00 \\
\hline \multirow[t]{2}{*}{ Vol. VIII } & -1982 & New Essays in Ethics and & & \\
\hline & & Public Policy & 14.00 & 13.00 \\
\hline Vol. IX & -1983 & New Essays on Plato & 13.00 & 13.00 \\
\hline Vol. X & -1984 & New Essays on Aristotle & 14.00 & 14.00 \\
\hline Vol. XI & -1985 & New Essays in the Philosophy & 1400 & 1400 \\
\hline \multirow{2}{*}{ Vol. XII } & -1986 & Nuclear Weapons, Deterrence & & 14.00 \\
\hline & & and Disarmament & 12.00 & 10.00 \\
\hline \multirow[t]{2}{*}{ Vol. XIII } & -1987 & Science, Morality and & & \\
\hline & & Feminist Theory & 14.00 & 12.00 \\
\hline Vol. XIV & -1988 & Philosophy and Biology & 14.00 & 12.00 \\
\hline Vol. XV & -1989 & Analyzing Marxism & 25.00 & 21.00 \\
\hline Vol. XVI & -1990 & Canadian Philosophers - & & \\
\hline & & Celebrating Twenty Years of the & & \\
\hline \multirow{3}{*}{ Vol. XVII } & & Canadian Journal of Philosophy & 24.00 & 20.00 \\
\hline & -1991 & Aristotle and his Medieval & & \\
\hline & & Interpreters & 21.00 & 21.00 \\
\hline Vol. XVIII & -1992 & Return of the A Priori & 22.00 & 22.00 \\
\hline Vol. XIX & -1993 & Méta-Philosophie & 30.00 & 30.00 \\
\hline Vol. XX & -1994 & Biology \& Society & 30.00 & 30.00 \\
\hline Vol. XXI & -1995 & On the Relevance of Metaethics & 24.00 & 24.00 \\
\hline Vol. XXII & -1996 & Rethinking Nationalism & 30.00 & 30.00 \\
\hline Vol. XXIII & -1997 & Meaning and Reference & 20.00 & 20.00 \\
\hline Vol. XXIV & -1998 & Pragmatism & 22.00 & 22.00 \\
\hline Vol. XXV & -1999 & Civilization and Oppression & 22.00 & 22.00 \\
\hline
\end{tabular}

Postage and Handling (Canada/U.S.A.) is $\$ 5.00$ (1-3 books). Postage and Handling (outside Canada) is $\$ 9.00$.

Canadian orders must include $7 \%$ GST on the total cost of the book(s) as well as the postage and handling.

Prices outside Canada are in US dollars.

Order University of Calgary Press

Fax Orders:

From: $\quad$ c/o Raincoast Distribution Services

8680 Cambie Street

$1-800-565-3770$

Vancouver, BC V6P 6M9

Email: custserv@raincoast.com 


\section{UNIVERSITY OF CALGARY PRESS}

\section{Meaning and Reference}

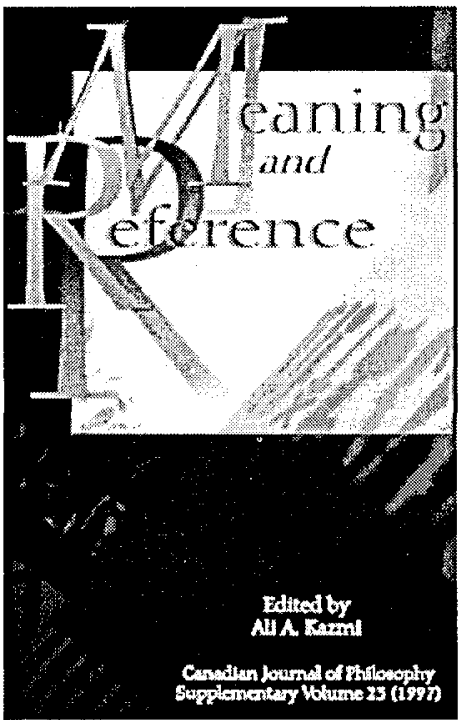

Includes:

Terence Parsons - Missing Modes of Supposition John Burgess - Quinus ab Omni Naevo Vindicatus Richard Cartwright - On Singular Propositions Nathan Salmon - Is de re Belief Reducible to de dicto?

George Wilson - On Some Untamed Anaphora Vann McGee - "Kilimanjaro"

Mark Richard - Inscrutability

Scott Soames - Skepticism about Meaning: Indeterminacy, Normativity, and the Rule-Following Paradox

\section{Kazmi, Ali, editor}

Canadian Journal of Philosophy, Supplementary Volume XXIII (1997)

$\$ 20.00$ (Outside Canada: \$US20.00) ISBN 0-919491-23-5 ISSN 0229-7051 $\mathrm{vi}+260 \mathrm{pp}$. biblio, index $5.5 \times 8.5 \mathrm{in}$. June 1998

This is a collection of eight new essays by some of the most prominent contemporary philosophers of language. These essays cover a variety of topics including scepticism about meanining and reference, vagueness, rigid designation, de re belief, pronominal anaphora, Quinean objections to quantified modal logic, and supposition. This volume will be of interest to anyone who works in the philosophy of language and philosophical logic.

Ali Kazmi is an editor of the Canadian Journal of Philosopby and an associate professor of philosophy at the University of Calgary.

\section{Order from Raincoast Distribution Services 8680 Cambie Street, Vancouver BC V6P 6M9 \\ Telephone: 1-800-663-5714 \\ Fax: 1-800-565-3770 \\ E-mail: custserv@raincoast.com}

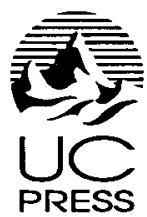




\section{UNIVERSITY OF CALGARY PRESS}

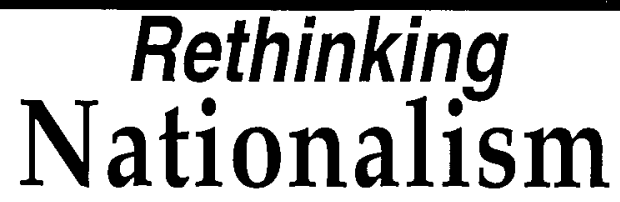

J. Couture, K. Nielsen \& M. Seymour, eds.

Canadian Journal of Philosophy, Suppl. Volume XXII $\$ 30.00 \cdot 700$ pp. • ISBN 0-919491-22-7 • ISSN 0229-7051

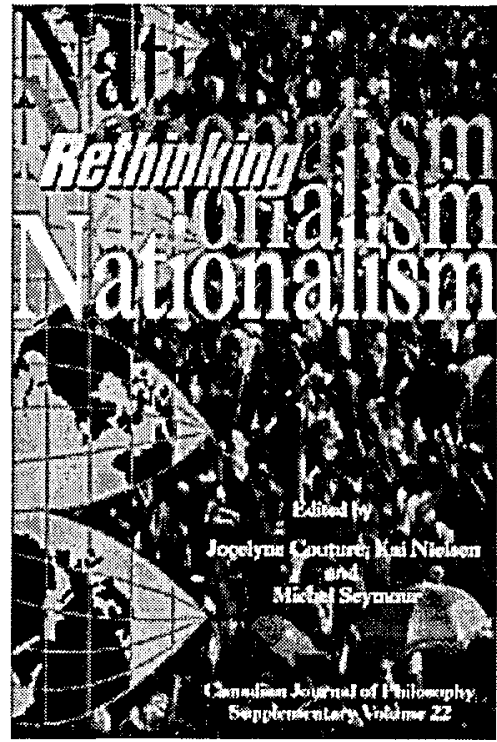

This formidable volume of seventeen essays and an extensive Introduction and Afterword contains some of the most innovative samples of present reflection on this contentious subject.

Contributions are from a variety of disciplines, from different parts of the world, often reflecting very different ways of thinking about nationalism and sometimes reflecting very different methodologies, substantive beliefs, and underlying interests.

Including: Introduction: Questioning the Ethnic/Civic Dichotomy $\bullet$ Michel Seymour, Jocelyne Couture and Kai Nielsen

Theoretical Difficulties in the Study of Nationalism • Yael Tamir

Is Nationalism Legitimate? A Sociological Perspective on a Philosophical Question - Liah Greenfeld

How Ethnic Enmities End - Barrington Moore, Jr.

Nationalism and Social Complexity $\bullet$ Robert Ware

\section{Order from:}

Raincoast Distribution Services

8680 Cambie Street, Vancouver BC V6P 6M9

Telephone: 1-800-663-5714 Fax: 1-800-565-3770

E-mail: custserv@raincoast.com

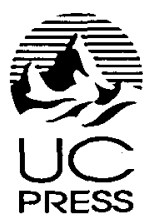




\section{UNIVERSITY OF CALGARY PRESS \\ On the Relevance of Metaethics}

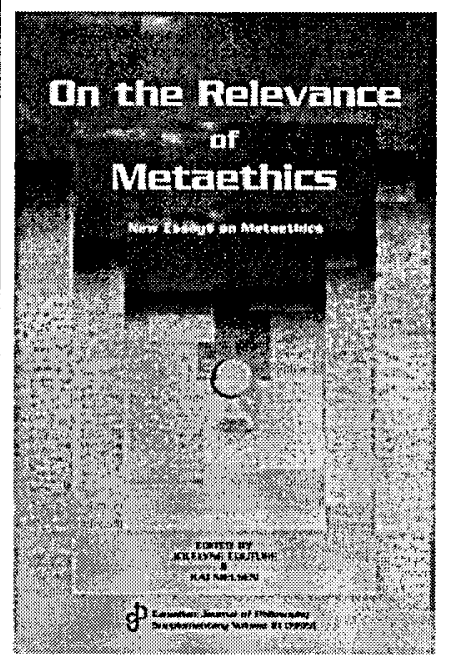

\section{Contents include:}

- Jocelyne Couture and Kai Nielsen Introduction: The Ages of Metaethics - Francis Sparshott

On Metaethics: A Reverie

- Richard B. Brandt

Foundationalism for Moral Theory

- R.M. Hare

Off on the Wrong Foot

- Peter Railton

Made in the Shade: Moral

Compatibilism and the Aims of

Moral Theory

- Jean Hampton

Naturalism and Moral Reasons

- Isaac Levi

Perception as Input and as Reason for Action

\section{New Essays on Metaethics} Jocelyne Couture and Kai Nielsen, editors

Canadian Journal of Philosophy, Supplementary Volume XXI

$\$ 24.00$ (Outside Canada: \$US24.00) ISBN 0-919491-21-9 ISSN 0229-7051 354 pp., $5.5 \times 8.5 \mathrm{in}$.

Around mid-century metaethics held centre stage in discussions of moral philosophy in Anglo-American and Scandinavian philosophical environments. During the 1970s, its "foundational" position was challenged by developments within analytic philosophy itself, by a renewal of systematic substantive ethics largely, but not exclusively, of a Rawlsian inspiration and by a reinvigorated interest in substantive moral problems on the part of philosophers. However, as work went on here, philosophers encountered problems concerning the methods of moral reasoning and the structure of justification of moral claims that were recognized to be metaethical. This led to a renewal of metaethics now freed from its previously narrow linguistic focus and aprioristic restrictions.

The essays in this volume contribute both to this renewal and to a continued skeptical probing of the very rationale of moral philosophy.

\section{Order from Raincoast Distribution Services}

8680 Cambie Street, Vancouver BC V6P 6M9

Telephone: $1-800-663-5714$

Fax: 1-800-565-3770

E-mail: custserv@raincoast.com

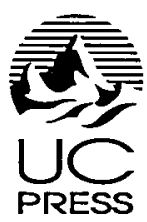




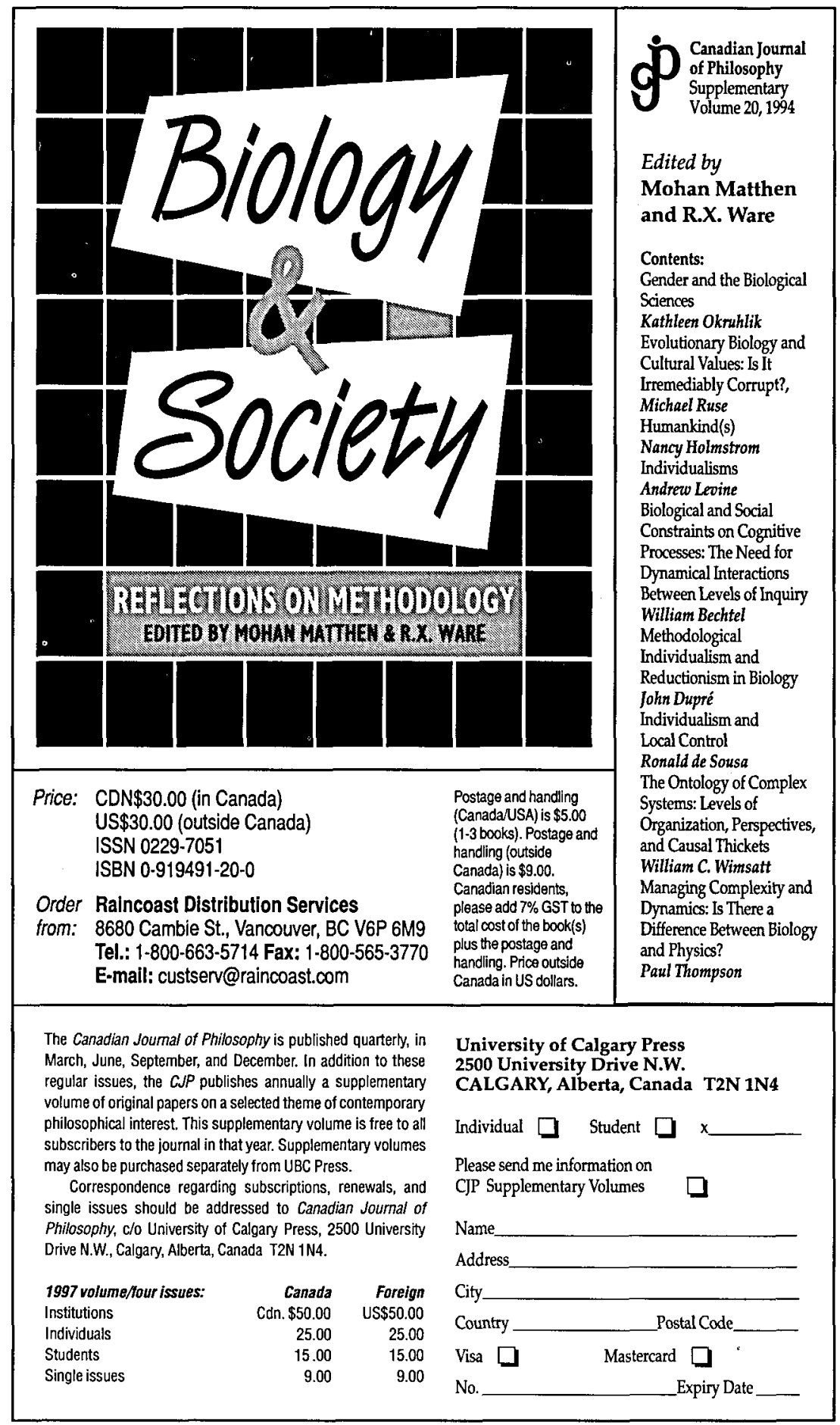




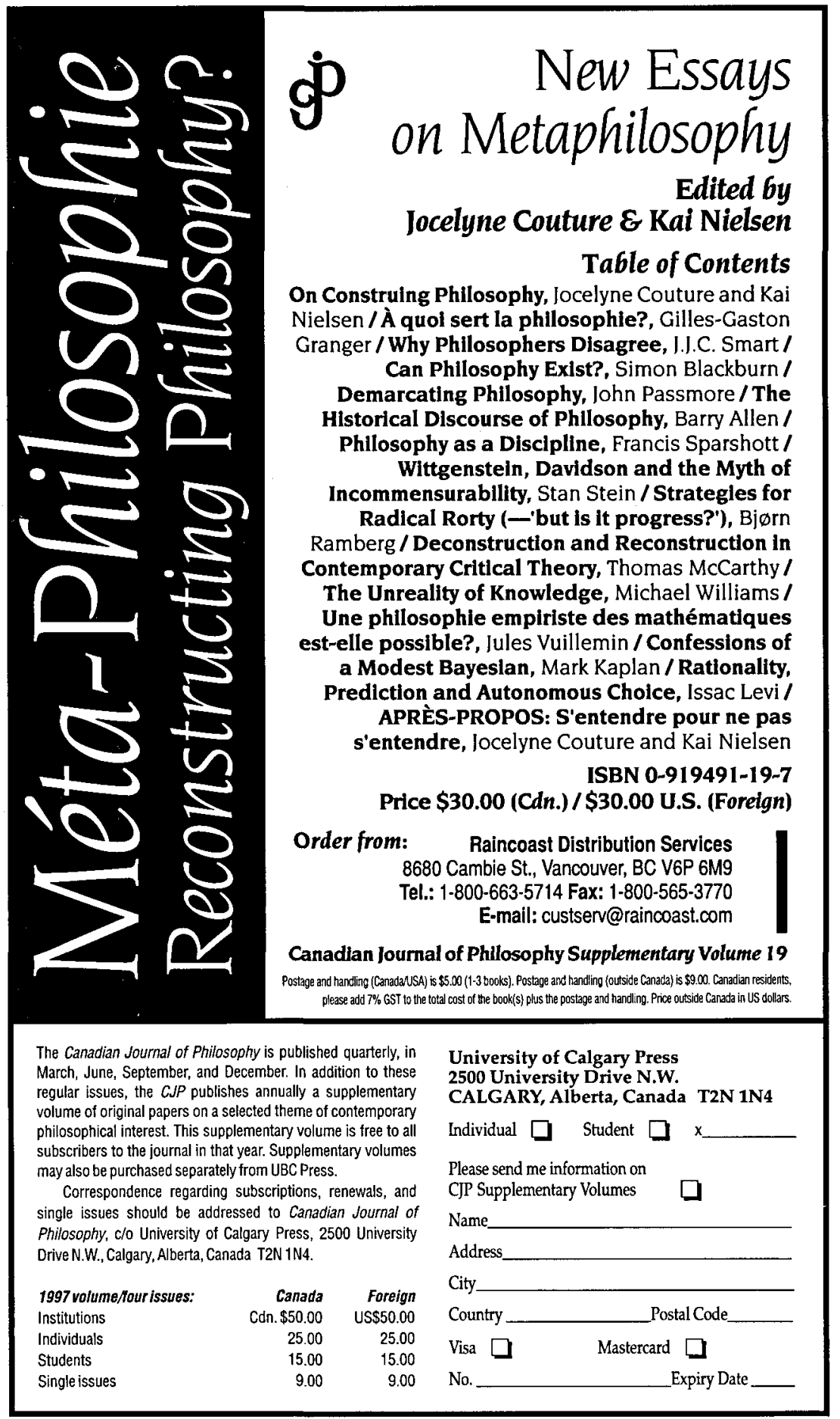




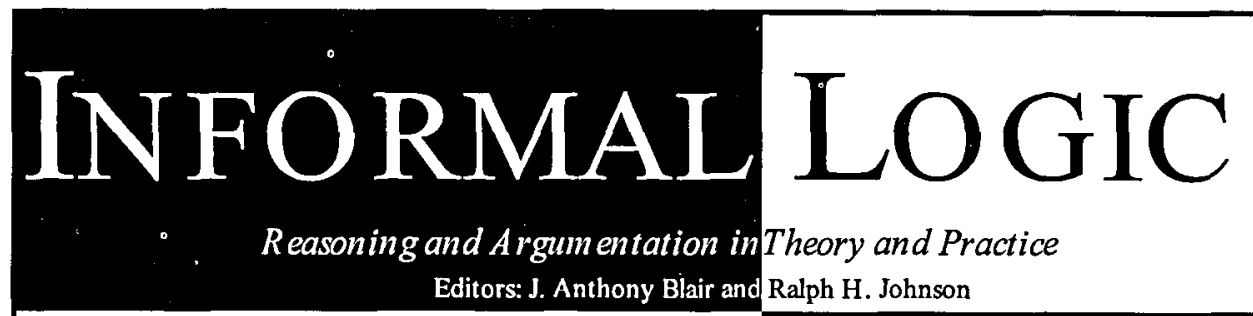

INFORMAL LOGIC publishes articles which advance the dialectic in reasoning and argumentation in theory and practice, including but not restricted to: theory of argument, fallacy analysis and fallacy theory, criteria of good argument, rationality and argument, psychology of argumentation, argument fields, theory of critical thinking, the teaching of argumentation, informal logic, and critical thinking, as well as related topics in cognate fields.

\section{TEaChing SuPPlement}

Starting with volume 20 , every edition of INFORMAL LOGIC will contain a teaching supplement with examples for use in critical thinking or reasoning skills courses - an invaluable tool for instructors.

Rates per volume ( 3 issues)

Canada (in CDN\$): individuals 40.00 , institutions 65.00. USA (in US\$): individuals 40.00 , institutions 65.00. Elsewhere (in US\$): individuals 43.00 , institutions 70.00 . Students (CDN/US): 25.00 . (All applicable taxes and shipping charges included. Make cheque or money order payable to INFORMAL LOGIC.)

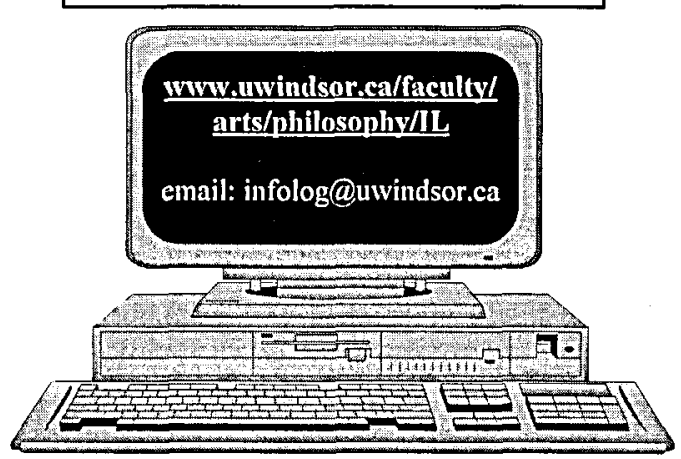

\section{INFORMAL LOGIC INDEX}

By the year 2000, an index of all articles published in INFORMAL LOGIC will be available through our web site.

\section{INFORMAL LOCiIC}

Department of Philosophy

University of Windsor

Windsor, Ontario, Canada N9B $3 P_{4}$

Phone: (519) 253-3000, x2332 Fax: (519) $971-3610$ 


\section{The}

Southern Journal of

Philosophy

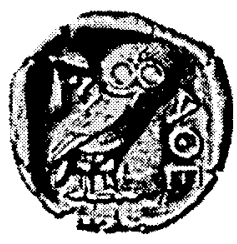

Spindel Conference proceedings only $\$ 12.00$ each

Spindel Conference 2000

Hegel's Philosophy of Right

Directed by Thomas Nenon

(proceedings available in 2001 supplement Vol. XXXIX)

The Role of the Empirical (and of the A Priori) in Epistemology

(available Spring 2000) - Vol. XXXVIII

Nietzsche and Politics - Vol. XXXVII

Kant's Metaphysics of Morals - Vol. XXXVI

Rethinking Sex and Gender - Vol. XXXV

Explanation in the Human Sciences - Vol. XXXIV

Vagueness - Vol. XXXIII

Derrida's Interpretation of Husserl - Vol. XXXII

Ancient Minds - Vol. XXXI

Kant's Third Critique - Vol. XXX

Moral Epistemology - Vol. XXIX

Heidegger and Praxis - Vol. XXVIII

Aristotle's Ethics - Vol. XXVII

Connectionism - Vol. XXVI

B-Deduction - Vol. XXV

Moral Realism - Vol. XXIV

Recovering the Stoics - Vol. XXIII

Supervenience - Vol. XXII

Rationalist Conception of Consciousness - Vol. XXI

For more information please write or call:

THE SOUTHERN JOURNAL OF PHILOSOPHY

THE UNIVERSITY OF MEMPHIS

329 CLEMENT HALL

3704 WALKER AVENUE

MEMPHIS TN 38152-0001

(901) 678-2669

FAX (901) 678-4365

Please visit our web site at:

HTTP://CAS.MEMPHIS.EDU/PHILOSOPHY/SJP 







\section{Biology \& Philosophy}

Editor:

Michael Ruse

University of Guelph, Dept. of Philosophy and Zoology, Ont., Canada

The past decades have witnessed fascinating and controversial advances in the biological sciences. One may think, for instance, of methods for analyzing the basic molecular units of heredity; of proposals and clarifications of the appropriate methods of classifying organisms; of exciting new ideas about the nature of the fossil record and their implications for the elucidation of evolutionary mechanisms; and of ways in which the biological study of behavior has been extended, theoretically and experimentally, and of supposed implications for humankind. To add to these internal issues, the outside world has also seen much debate on biology \&ndash; in the world of education, for instance. These and other issues have made biology one of the most exhilarating areas of science, and have aroused in biologists and philosophers an awareness that there is a need for meta-theoretical analysis, both about the very nature of biology, as well as about its social implications. Biology and Philosophy is aimed at a broad readership, drawn from both the sciences and the humanities. The journal subscribes to no specific school of biology, nor of philosophy, and publishes work from authors of all persuasions and all disciplines. The editorial board reflects this attitude in its composition and its world-wide membership. Each issue of Biology and Philosophy carries one or more discussions or comparative reviews, permitting the in-depth study of important works and topics.

'Biology and Philosophy has started well...it will perform a genuine service...this is a journal that no thoughtful biologist should ignore.'

\section{Nature}

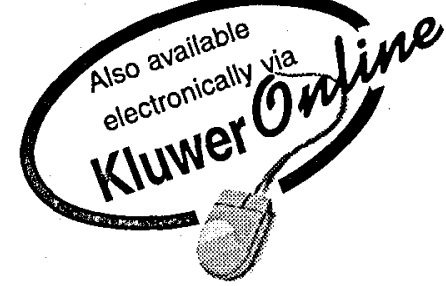

Special rate for the International Society for the History, Philosophy and Social Studies of Biology: USD 50.00, incl.p/h.

Information through http//www.phil.ut.edu/ISHPSSB/member.html or contact David Magnus, treasurer Magnus@mail.med.upenn.edu Special subscription rate for ISHPSSB members to both 'Biology and Philosophy' and 'Journal of the History of Biology': USD 90.00, incl.p/h.

P. 0. Box 322, 3300 AH Dordrecht, The Netherlands P.O. Box 358, Accord Station, Hingham, MA 02018-0358,U.S.A.

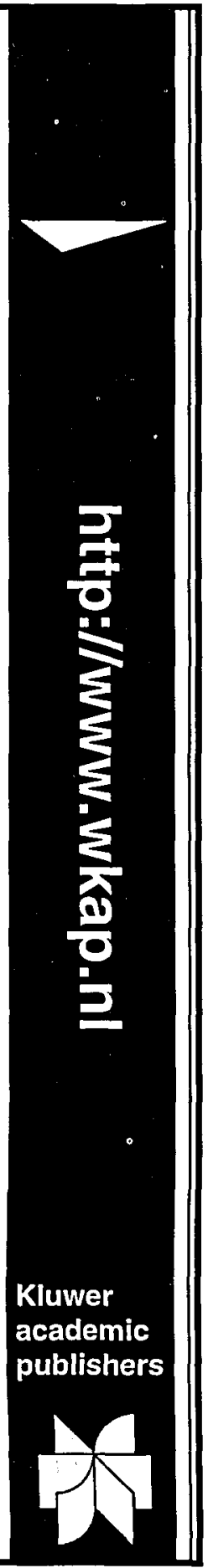




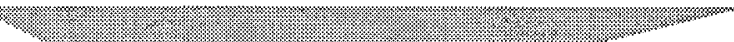 Studies in East European Thought}

Founding Editor:

J.M. Bochenski

Managing Editor:

Edward M. Swiderski

IEO, University of Fribourg, Switzerland

Editorial Assistants:

Frances Nethercott, Fribourg, Switzerland

Evert van der Zweerde, Faculty of Philosophy, University of Nijmegen, The Netherlands

Book Review Editor:

William J. Gavin, Portland, ME, USA

Studies in East European Thought is intended to provide a forum for Western-language (English and German) writings on philosophy and philosophers who identify with the history and cultures of East and Central Europe, including Russia, Ukraine, and the Baltic States. The editors do not advocate a program or defend a position as to the nature and limits of philosophy in its manifold interactions with other disciplines and in its role in articulating cultural values and marking intellectual dissonances. They welcome descriptive, critical, comparative, and historical studies of individuals, schools, currents, and institutions whose work and influence are widely regarded in their own environments to be philosophical or provide insight into the sociocultural conditions of philosophical life in Eastern Europe.

International Advisory Board:

Karl G. Ballestrem, David Bakhurst, Helmut Dahm, Richard DeGeorge, Aleksandr Dobrochotov, Peter Ehlen, Philip Grier, Abdusalam Gusejnov, Assen Ignatow, George L. Kline, Alex Kozulin, Guido Küng, Nikolaus Lobkowicz, Christoph Nyíri, Jan Pavlik, Tom Rockmore, Bernice Rosenthal, James P. Scanlan, Erich Jurevich Solov'ëv, Jan Wolenski

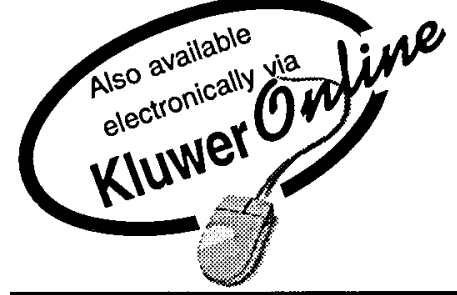

Subscription Information 2000 , Volume 52 (4 issues) ISSN 0925-9392

Subscription Rate: NLG 540.00/USD 257.00, incl.p/h.

P.0. Box 322, 3300 AH Dordrecht. The Netherlands P.0. Box 358, Accord Station, Hingham, MA 02018-0358,U.S.A.

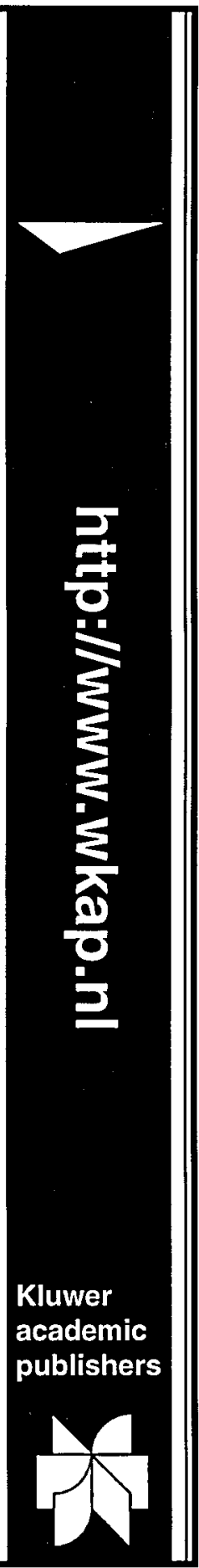




\section{Theory and Society}

Renewal and Critique in Social Theory

Founding Editor:

Alvin W. Gouldner

Advisory Editor:

Robert K. Merton

Columbia University

Executive Editor:

Janet Gouldner, University of California at Davis, USA

Managing Editor:

Karen G. Lucas, Dept. of Communication, University of Missouri, St. Louis, USA

Assistant Managing Editor:

Zach Schiller, Sociology Dept., University of California, Davis

Editors:

Bob Connell, Paul DiMaggio, Anthony Giddens, Martin Jay, Chandra Mukerji, Ivan Szelenyi, Charles Tilly, Vera Zolberg, Sharon Zukin

\section{Book Review Editors: \\ Carl Boggs, Richard Colignon, Martin Jay, David Swartz}

Theory and Society is a forum for the international community of scholars that publishes theoretically-informed analyses of social processes. It opens its pages to authors working at the frontiers of social analysis, regardless of discipline. Its subject matter ranges from prehistory to contemporary affairs, from treatments of single individuals and national societies to world culture, from discussions of theory to methodological critique, from First World to Third World but always in the effort to bring together theory, criticism and concrete observation.

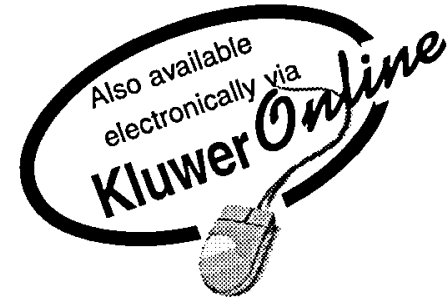

Subscription Information 2000, Volume 29 (6 issues) ISSN 0304-2421 Subscription Rate: NLG 760.00/USD 362.00, incl.p/h.

P.0. Box 322, 3300 AH Dordrecht, The Netherlands P.O. Box 358, Accord Station, Hingham MA 02018-0358, U.S.A.

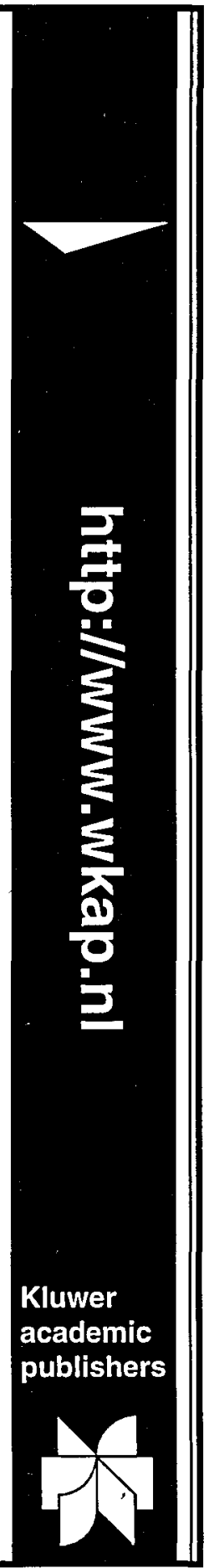




\title{
Philosophical Studies
}

\author{
An International Journal for \\ Philosophy in the Analytic Tradition
}

\author{
Editor-in-Chief: \\ Stewart Cohen \\ Arizona State University, Tempe, USA \\ Editor: \\ Keith Lehrer \\ University of Arizona, Tucson, USA
}

Philosophical Studies was founded in 1950 by Herbert Feigl and Wilfrid Sellars to provide a periodical dedicated to work in analytic philosophy. The journal remains devoted to the publication of papers in exclusively analytic philosophy. Papers applying formal techniques to philosophical problems are welcome. The principal aim is to publish articles that are models of clarity and precision in dealing with significant philosophical issues. It is intended that readers of the joumal will be kept abreast of the central issues and problems of contemporary analytic philosophy.

\section{Editorial Assistant:}

Jason Decker, Arizona State University, Tempe, USA

\section{Board of Consulting Editors:}

Lynne Rudder Baker, Michael Bratman, Philip Bricker, Richard Creath, Wayne Davis, Michael Devitt, M.A.E. Dummett, Fred Feldman, Hartry Field, John Fischer, Greg Fitch, Gilbert Harman, Frank Jackson, Bernard W. Kobes, Vann McGee, Ruth Millikan, Ronald Milo, John O'Leary-Hawthorne, Nathan Salmon, Stephen Schiffer, Brian Skyrms, Holly M. Smith, Ernest Sosa, Stephen Stich, Judith Thomson, Joseph T. Tolliver, Peter van Inwagen, Michael White, Steve Yablo

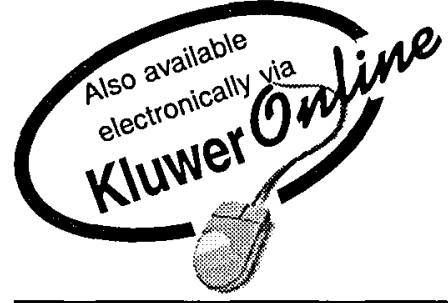

Subscription Information 2000 , Volumes $97-101$

(15 issues)

ISSN $0031-8116$

Subscription Rate:

NLG 2147.50/USD 1023.00, incl.p/h.

P.0. Box 322,3300 AH Dordrecht, The Netherlands. P.O. Box 358. Accord Station, Hingham MA 02018-0358. U.S.A.

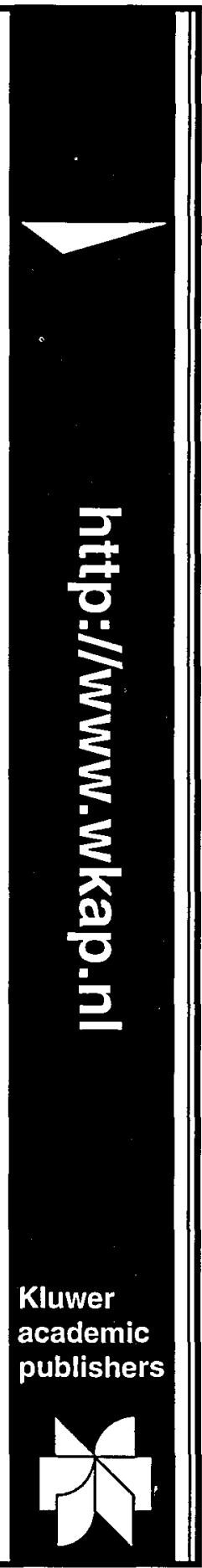


Journal of

\title{
Philosophical Logic
}

\author{
Published under the Auspices of the \\ Association for Symbolic Logic
}

\section{Editor:}

\section{Vann McGee}

Dept. of Philosophy, Rutgers University, New Brunswick, NJ, USA

Krister Segerberg

Dept. of Philosophy, Uppsala University, Sweden

The Joumal of Philosophica/ Logic publishes papers that utilize formal methods or that deal with topics in logical theory, such as:

- Contributions to branches of logical theory directly related to philosophical concerns, such as inductive logic, modal logic, deontic logic, quantum logic, tense logic, free logic, logic of questions, logic of commands, logic of preference, logic of conditionals, many-valued logic, and relevance logics.

- Contributions to philosophical discussions that utilize the machinery of formal logic, as in recent treatments of abstract entities, non-existent possibles, essentialism, existence, propositional attitudes, meaning and truth.

- Discussions of philosophical issues relating to logic and the logical structure of language, such as conventionalism in logic, ontic commitment, logical or semantic paradoxes, the logic of hypotheses and of pre-suppositions, constructivism, and extensionality.

- Philosophical work relating to specific sciences (such as linguistics, history of logic, or physics), with an emphasis on foundational problems, and making use of logical theory. Some instances of recent work of this kind are the treatments of universal grammar, pragmatics, conceptions of possibility, theories and mathematical truth in the history of philosophy, formalization of scientific theories, or logical structure in quantum mechanics.

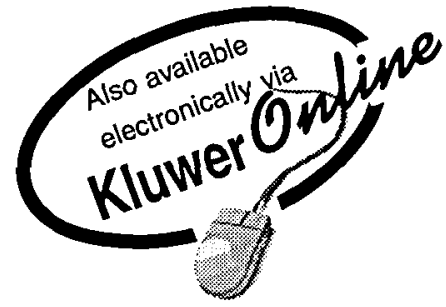

Subscription Information 2000 , Volume 29 (6 issues) ISSN 0022-3611

Subscription Rate: NLG 870.00/USD 414.00, incl.p/h.

Special rate for ASSL:

USD 30.00

(incl. administrative costs)

P.0. Box 322, 3300 AH Dordrecht, The Netherlands P.0. Box 358, Accord Station, Hingham, MA 02018-0358,U.S.A.

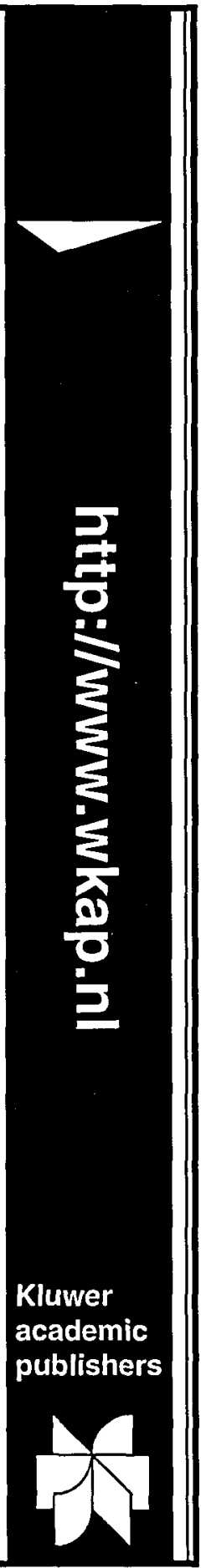




\title{
Synthese
}

\section{An International Journal for Epistemology, Methodology and Philosophy of Science}

\author{
Editor-in-Chief: \\ Jaakko Hintikka \\ Dept. of Philosophy, Boston University, MA, USA
}

Synthese publishes articles in the theory of knowledge, the general methodological problems of science, such as the problems of scientific discovery and scientific interest, of induction and probability, of causation and of the role of mathematics, statistics and logic in science, the methodological and foundational problems of the different departmental sciences, insofar as they have philosophical interest, those aspects of symbolic logic and of the foundations of mathematics which are relevant to the philosophy and methodology of science, and those facets of the history and sociology of science which are important for contemporary topical pursuits. Particular attention is paid to the role of mathematical, logical and linguistic methods in the general methodology of science and the foundations of the different sciences, be they physical, biological, behavioral or social. Most of the issues of synthese are organized into thematic issues, taking the character of symposia dealing with described themes.

\section{Editors:}

James H. Fetzer, Dept. of Philosophy, University of Minnesota, Duluth, USA; Risto Hilpinen, University of Turku, Finland, Barry Richards, Imperial College of Science, Technology and Medicine, London, UK; Paul Humphreys, (and Book Review Editor), Dept. of Philosophy, University of Virginia, USA

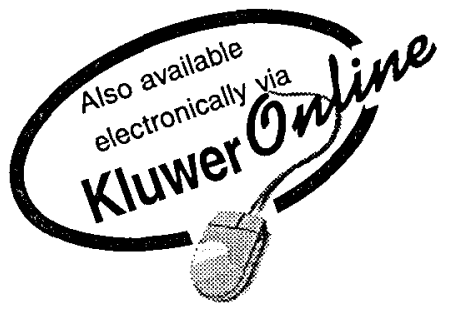

Subscription Information 2000 , Volumes $122-125$ (12 issues) ISSN 0039-7857

Subscription Rate: NLG 2200.00/USD 1048.00, incl.p/h. Special rate for APA: NLG 1072.00/USD 536.00, incl.p/h.

P.0. Box 322, 3300 AH Dordrecht, The Netherlands P.O. Box 358, Accord Station, Hingham. MA 02018-0358,U.S.A.

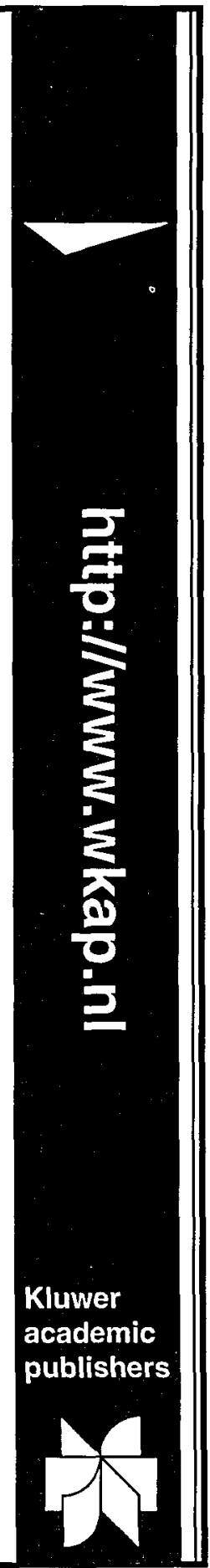




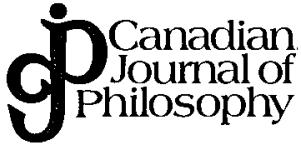

Acknowledge- Canadian Journal of Philosophy is published with the aid of a ments/ grant from the Social Sciences and Humanities Research Council Remerciements of Canada.

La publication du Canadian Journal of Philosophy est rendue possible grâce à une subvention du Conseil de Recherches Humaines du Canada.

Canadian Journal of Philosophy wishes to thank the University of Lethbridge for its generous support for the editorial administration of the journal.

Canadian Journal of Philosophy tient à remercier l'Université de Lethbridge de l'aide généreuse qu'elle apporte à la gestion de sa rédaction.

Canadian Journal of Philosophy is grateful for past support from its originating sponsor, the Canadian Association for Publishing in Philosophy.

Canadian Journal of Philosophy désire exprimer sa gratitude à l'Association Canadienne des Publications en Philosophie qui l'a aide par le passé. 